\title{
Motivation of classroom attendance students for the use of digital technologies in online courses
}

\author{
Motivação de alunos de cursos presenciais para o uso de \\ tecnologias digitais em disciplinas on-line \\ Motivación de alumnos de cursos presenciales para el uso \\ de tecnologías digitales en disciplinas on-line
}

\author{
Fernanda Regina Antunes ${ }^{a}$ \\ Alfredo Almeida Pina-Oliveira ${ }^{b}$ \\ Maíra Rosa Apostolico ${ }^{b}$ \\ Ana Cláudia Giesbrecht Puggina ${ }^{c}$
}

\section{How to cite this article:}

Antunes FR, Pina-Oliveira AA, Apostólico

MR, Puggina ACG. Motivation of classroom attendance students for the use of digital technologies in online courses. Rev Gaúcha Enferm. 2020;41:e20190289. doi: https://doi.org/10.1590/19831447.2020.20190289
Universidade Paulista (UNIP). São Paulo, São Paulo, Brasil.

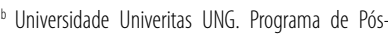
Graduação em Enfermagem. Guarulhos, São Paulo, Brasil.

( Faculdade de Medicina de Jundiaí (FMJ). Jundiaí, São Paulo, Brasil.

\section{ABSTRACT}

Objective: To verify if structural aspects, previous use of digital technologies, and ways of studying by classroom attendance students interfere with motivation in the use of these technologies in online courses.

Method: A quantitative cross-sectional study was carried out with 713 university students, from May to September 2015, with the use of an evaluation scale for motivational factors regarding the integration of information and communication technologies in education. Descriptive and inferential statistical analysis of the data was carried out.

Results: Desire to attend online courses interfered with four of the five scale factors. Having a space for studying and the way students reported learning better interfered with intrinsic motivation ( $p=0.006$ and $p=0.017$, respectively).

Conclusion: Predisposition to attend online courses, having an appropriate space to study, and reconciling studies with the use of other websites were positive elements for motivation of students in online courses.

Keywords: Distance Education. Higher Education. Educational technology. Communication. Motivation.

\section{RESUMO}

Objetivo: Verificar se aspectos estruturais, uso prévio das tecnologias digitais e maneira de estudar de alunos de cursos presenciais interferem na motivação no uso dessas tecnologias em disciplinas on-line.

Método: Estudo transversal quantitativo realizado com 713 estudantes universitários, entre maio e setembro de 2015. Foi aplicada a Escala de Avaliação de Fatores de Motivação com Relação à Integração das Tecnologias de Informação e Comunicação ao Ensino. Realizou-se análise estatística descritiva e inferencial dos dados.

Resultados: A vontade de fazer um curso a distância interferiu em quatro dos cinco fatores da escala. Ter um espaço para estudos e a maneira que 0 aluno refere aprender melhor interferiram interferiu na motivação intrínseca ( $p=0,006$ e $p=0,017$, respectivamente). Conclusão: Predisposição para fazer algum curso a distância, ter um espaço adequado para estudar e conciliar os estudos com o uso de outros sites foram elementos positivos para a motivação dos alunos em disciplinas on-line.

Palavras chave: Educação a distância. Educação superior. Tecnologia educacional. Comunicação. Motivação.

\section{RESUMEN}

Objetivo: Verificar si los aspectos estructurales, el uso previo de las tecnologías digitales y la manera de estudiar de los estudiantes de los cursos presenciales interfieren en la motivación en el uso de estas tecnologías en las materias on-line.

Método: Estudio transversal cuantitativo realizado con 713 estudiantes universitarios entre mayo y septiembre de 2015. Se aplicó la Escala de Evaluación de Factores de Motivación con relación a la Integración de las Tecnologías de Información y Comunicación a la Enseñanza. Se realizó un análisis estadístico descriptivo e inferencial de los datos.

Resultados: La voluntad del alumno de hacer un curso a distancia interfirió en cuatro de los cinco factores de la escala. Tener un espacio para estudios y la manera que el alumno se refiere a aprender mejor interfirió en la motivación intrínseca ( $p=0,006$ y $p=$ 0,005 respectivamente).

Conclusión: la disposición a hacer algo curso a distancia, tener un espacio adecuado para estudiar y conciliar los estudios con el uso de otros sitios fueron elementos positivos para la motivación de los estudiantes en las materias on-line.

Palabras clave: Educación a distancia. Educación superior. Tecnología educacional. Comunicación. Motivación. 


\section{口INTRODUCTION}

Inclusion of digital information and communication technologies (DICTs) has increased worldwide. In order to include new learning trends and meet the needs of future generations, higher education institutions (HEls) must adapt to changes and restructure their ways of dealing with and including best pedagogical and technological practices.

DICTs include a wide range of equipment, programs, and media that allow network integration of individuals, especially the Internet. Educational processes in the digital era benefit from the use of virtual learning environments (VLES) to support distance education (DE) and hybrid education ${ }^{(1)}$.

Therefore, hybrid education values synergy between classroom attendance and online strategies for knowledge construction through customized, collaborative, and interactive opportunities. It has as objectives recognizing different learning styles, providing problem-solving exercises, encouraging experience exchange, providing feedback, and clearing up students' doubts ${ }^{(1)}$.

It is of the utmost importance to access how students' behavioral aspects regarding DICTs ${ }^{(2)}$ and the individual and institutional conditions of professors ${ }^{(3)}$ influence the inclusion of technological innovations and the initial training of undergraduate healthcare students in the Brazilian context.

Understanding the social context and digital inclusion of undergraduate students is essential for the implementation of access to VLE and other online platforms. In order to foster education that considers the need for individual learning and market expectations ${ }^{(3-4)}$, DICTs must be understood as providing support, resources, and methods that allow learning activities to be undertaken in different and innovative ways $s^{(1,4)}$.

Therefore, the motivation of undergraduate students in the use of more dynamic, engaging, and challenging strategies for the development of autonomy and creativity becomes of utmost importance in encouraging good academic performance and learning fulfillment ${ }^{(5)}$.

Motivation is a plural, complex, and interdisciplinary concept, and contributes to an understanding of the learning process. Among the theoretical models of this area, the present study is grounded in the self-determination theory (SDT) developed by Deci and Ryan, used as a path that is based on the search for autonomy, competence, and relatedness, aiming at understanding psychological needs, with a focus on the promotion of personal development, integrity, and well-being of individuals ${ }^{(6)}$. These authors posit a self-determination continuum for the regulation of human behavior in specific situations that includes intrinsic and extrinsic motivation.
Intrinsic motivation involves activities that awaken the desire and interest of individuals in engaging in behavior itself and feeling spontaneous satisfaction in their performance. However, extrinsic motivation requires instrumentality between activities and tangible and verbal external rewards associated with challenges, tasks, situational contingence, and sociocultural aspects that result in external consequences produced by activities ${ }^{(6)}$. Therefore, for SDT, amotivation represents absence of motivation and intentional regulation.

Understanding the motivation of undergraduate students in the implementation of DICTs does not consider learning styles, socioeconomic contexts of students, access to the Internet, and aspects of HEls, which are essential to making time and space more flexible for teaching and learning in the digital era.

Considering this issue, and the lack of scientific articles in the Brazilian and international literature on motivation of students for the use of DICTs, the present study sought to answer to the following guiding question: Which structural aspects interfere with motivation of students for learning with the use of digital information and communication technologies?

Therefore, the objective of the present study was to verify if structural aspects, previous use of digital technologies, and ways of studying of classroom attendance students interfere with motivation in the use of these technologies in online courses.

\section{$\square$ METHOD}

This was a quantitative cross-sectional study carried out with students of courses in the healthcare area of a private HEl in the state of São Paulo.

The HEl offered classroom attendance and full-time online courses distributed in the curricula of undergraduate courses. All healthcare courses presented regular and elective online courses. At the time of data collection, the Modular Object-Oriented Dynamic Learning Environment (Moodle) was used as a virtual learning environment.

The HEl offered 22 online courses, of which 19 were available for healthcare area courses, as follows: biosafety; citizenship and social responsibility; computers and society; communication and expression; Brazilian culture; digital law; the Brazilian economy; environmental education; entrepreneurship; epidemiology; human resources; project management; management and society; health management; scientific methodology; scientific research methodology; security and system audits; biotechnology; and health surveillance. Undergraduate students in the healthcare area are required to take four to six courses during their studies. 
These courses followed a structure of eight units of two classes each, using pdfs with just textual content. At the end of each unit, students took a test with ten multiple-choice questions with five answer options each. In addition, the two teaching strategies were used: discussion groups on a previously proposed theme; and contextualized activities where students created texts about a specific theme.

The IT structure of the HEl was made up of 13 computer laboratories with 20 to 50 computers. All the laboratories were networked and had fixed projectors. IT laboratories were available for students to use in the absence of classes. In addition, Wi-Fi was available on all the University campuses for students.

The representative sample for the population of the nursing, biomedicine, physical education, and pharmacy programs was calculated by means of the statistical program STATS 2, considering a 5\% maximum acceptable error, 50\% estimated percentage level, and 95\% confidence interval (Chart 1).

A convenience sample was utilized. After authorization from the institution and professors of classroom attendance courses, students were personally recruited between classes, when the researchers explained the objectives of the study and handed out informed consent forms and printed questionnaires. The participants filled out the questionnaires, signed the consent forms, and returned them to the researchers on the same day, sometimes right away and sometimes by the end of the final class. Students of the institution studied in specified classrooms during the semester, which enabled data collection mapping by the researchers. Only one researcher applied all the instruments collected in the present study. The following inclusion criteria were considered: being more than 18 years old; having already attended at least one online course in the HEl; and attending between the 2nd and 8th semesters. Data collection occurred from May to September 2015.

The dependent variable of the study was motivation in the use of DICTs. Information on structural aspects, use of digital technologies, and ways of studying with the use of digital technologies were considered independent variables. The evaluation scale for motivation factors regarding the integration of information and communication technologies for education (EMITICE) ${ }^{(7)}$ was used. This psychometric instrument, which is based on self-determination theory, had been translated, adapted, and validated ${ }^{(7)}$ for the Brazilian reality, and was considered valid and reliable for that context. Confirmatory factor analysis showed the adequacy of the model and good internal consistency for the sample $(a=0.84)$.

The purpose of the instrument is to understand the study object by means of the following concepts: intrinsic motivation (individuals' involvement in an activity based on its inherent interest); extrinsic motivation (interest in an activity for the expected results); and amotivation (lack of impulse or inspiration to carry out an activity). Human personality and motivation are concentrated in changing trends, innate psychological needs, favorable conditions for motivation, social functioning, and personal well-being(7).

Although the EMITICE refers to the general use of DICTs in the university environment ${ }^{(7)}$, the participants in the present study answered to the questionnaire with a focus on the use of DICTs in the online courses offered by the HEI.

The scale, which presents 20 randomized affirmatives and five factors (amotivation, external control, internal control, identification control, and intrinsic motivation), was applied as outlined in the validation study. The items on the scale are evaluated by the following 7-point Likert scale: (1) No correlation at all, (2) Almost no correlation, (3) Slight correlation, (4) Moderate correlation, (5) Significant correlation, (6)

\begin{tabular}{|l|c|c|}
\hline Course & $\begin{array}{c}\text { Total number of students from } \\
\text { 2nd to 8th semester }\end{array}$ & \begin{tabular}{c} 
Minimum representative sample \\
\hline Nursing
\end{tabular} \\
\hline Biomedicine & 656 & 242 \\
\hline Physical Education & 234 & 145 \\
\hline Pharmacy & 361 & 186 \\
\hline Total & 220 & 140 \\
\hline
\end{tabular}

Chart 1 - Population and minimum representative sample of students per course. Guarulhos, São Paulo, Brazil, 2015. Source: Research data, 2015 
Strong correlation, and (7) Complete correlation. The total score ranges from 20 to 140, and the higher the total score, the higher the motivation in the use of DICTs in education ${ }^{(7)}$.

The questionnaire designed for student characterization contained six items on socioeconomic characteristics (gender, age, marital status, family income, course, and semester) and 12 questions on experience with digital technologies (structural aspects, use of DICTs, and ways of studying), totaling 18 questions. Questions on experience with digital technologies were developed based on the Digital UNG Student Profile Questionnaire, which was developed by a team of the digital UNG of the Univeritas UNG Guarulhos University.

Descriptive analysis of the data was carried out by means of absolute and relative frequencies, measures of central tendency (mean and median), and dispersion (standard deviation, minimum and maximum values).

The normality of the EMITICE total scores and factors were evaluated by means of the Komolgorow-Smirnov test for inferential analysis. Because they did not present normal distribution, non-parametric tests were applied. The Mann-Whitney test was used for comparison of scores according to two qualitative variables, and the Kruskal-Wallis test was used for comparison of qualitative variables with three or more groups. In this last case, Dunnett's test was applied when a statistically significant difference was found.

Spearman's correlation coefficient was used for comparing quantitative variables $(r)$. The following reference values for magnitude were found: $r=0.10$ to 0.39 , poor; $r=0.40$ to 0.69 , moderate; $r=0.70$ to 1 , strong ${ }^{(8)}$.

A descriptive level of $5 \%(p<0.05)$ was considered for statistical significance. The data were entered into an Excel ${ }^{\circ}$ spreadsheet and analyzed by means of the Statistical Package for the Social Sciences (SPSS), Version 22 for Windows ${ }^{\circ}$ and Graph Pad.

The present study showed that some variables suffered data imputation process through mode ${ }^{(9)}$. No differences were found in the distribution of measures of central tendency or variables of dispersion, because losses ranged from $0.1 \%$ to $1.8 \%$.

The present study met the standards of Resolution 466/2012 of the Brazilian National Health Council, which addresses research with human subjects, and was approved by the Research Ethics Committee of the University of Guarulhos under protocol no. 512.813. All participants signed an informed consent form.

\section{Q RESULTS}

The sample of present study was 713 students. The mean age was 26.6 years $( \pm 7.1)$. Most were women $(n=461$;
$64.6 \%$ ), were single ( $n=499 ; 70 \%$ ), and had an average monthly income of 3.9 minimum wages, approximately $\mathrm{R} \$ 3,432.00$ when the study was carried out. The participants were in the following program: nursing $(n=246$; $34.5 \%)$, physical education ( $n=182 ; 25.5 \%)$, biomedicine $(145 ; 20.3 \%)$, and pharmacy $(n=140 ; 19.6 \%)$. They were mostly enrolled in the third $(n=155 ; 21.7 \%)$ or fourth semester ( $n=145 ; 20.3 \%)$.

Regarding IT structural aspects, most students had computers at home, for private use. Notebooks were the devices most used to access online courses, and most students expected to study at home. Regarding the total number of electronic devices, considering tablets, iPads, iPods, cell phones, and computers, a mean of 4.0 pieces of equipment $( \pm 2.5)$ was found. However, $48 \%$ of the students considered their home spaces inappropriate for study (Table 1).

Most students found the use of DICTs easy, used their computers for everything, and used the Internet more for studying. Higher frequencies were found for students, who, when accessing the Internet, stayed only on pages regarding content (41.5\%) (Table 1).

Regarding ways of studying, most students (57.2\%) only chose to attend online courses that use strategies for both reading and individual activities and group discussions and videos; $43.2 \%$ of the students reported learning better when reading texts, making summaries, and carrying out activities; however, $35.8 \%$ reported a need to listen to explanations about some topics. Most students (64.4\%) reported that they would not take undergraduate or graduate online courses (Table 1).

The mean total score on the EMITICE in the sample studied was 78.5 ( $\pm 20.4 \%)$, showing low-o -moderate motivation, and was below the mean score on the instrument (80). Graph 1 shows the high median of the factor "amotivation" compared with the other factors.

In studies with psychometric instruments, analysis of absent data can yield results regarding denial or uncertainty of individuals about what is affirmed. Absent responses were more frequent in questions 5,14, and 17 of the instrument regarding preference/satisfaction regarding the use of DICTs, association of intelligence with ability to use technologies, and belief that mastery of DICTs increases professional skills.

The factor "intrinsic motivation" presented strong a positive correlation with the factors "external control" $(r=0.78$; $p<0.001)$, "internal control" $(r=75 ; p<0.001)$, and "identification control" $(r=0.83 ; p<0.001)$. There was a strong negative correlation ( $r=0.10 ; p=0.020)$ between the factors "intrinsic motivation" and "amotivation."

Statistically significant differences were found when comparing the factor External Control with the following 
Table 1 - Description of structural characteristics, ways of studying, and use of DICTs by the study participants. Guarulhos, São Paulo, Brazil, 2015

\section{Variables and categories}

n

\section{(\%)}

The device that you use MOST to access online courses is:

\begin{tabular}{|c|c|c|}
\hline Notebook & 485 & 68.0 \\
\hline Cell phone & 144 & 20.2 \\
\hline Desktop & 62 & 8.7 \\
\hline Tablet & 22 & 3.1 \\
\hline \multicolumn{3}{|l|}{ Where do you intend to carry out online studies? } \\
\hline Home & 618 & 86.7 \\
\hline University laboratories & 53 & 7.4 \\
\hline Work environment & 35 & 4.9 \\
\hline Homes of friends & 4 & 0.6 \\
\hline LAN gaming centers & 3 & 0.4 \\
\hline \multicolumn{3}{|l|}{ Regarding your space for studies, do you consider it: } \\
\hline Slightly appropriate & 342 & 48.0 \\
\hline Appropriate & 316 & 44.3 \\
\hline Inappropriate & 55 & 7.7 \\
\hline \multicolumn{3}{|l|}{ Regarding your computer, do you:** } \\
\hline Use it for everything and find it easy & 544 & 76.3 \\
\hline Need assistance, because you do not know how to use all resources & 109 & 15.3 \\
\hline Not like it and only use it when you need to & 52 & 7.3 \\
\hline Not feel comfortable with technology & 8 & 1.1 \\
\hline \multicolumn{3}{|l|}{ Do you use the Internet MOSTLY for: } \\
\hline Study & 379 & 53.2 \\
\hline Entertainment & 243 & 34.1 \\
\hline Communication with friends & 79 & 11.1 \\
\hline Shopping & 7 & 1.0 \\
\hline I do not have the habit of using the Internet & 5 & 0.7 \\
\hline \multicolumn{3}{|l|}{ When accessing the Internet to study: } \\
\hline Do you stay only on pages regarding contents? & 296 & 41.5 \\
\hline $\begin{array}{l}\text { Are you able to reconcile your study with social networks and other websites, } \\
\text { with good results at the end of the semester? }\end{array}$ & 279 & 39.1 \\
\hline Do you lose concentration by going to other websites? & 138 & 19.4 \\
\hline
\end{tabular}


Table 1 - Cont.

\section{Variables and categories}

n

(\%)

If you could choose how to study your online courses, would it be:*

By reading and individual activities, group discussions, and videos 268 37.6

By using automated resources, where you would do everything alone, without the presence of online professors

182

25.5

By only video lessons and group discussions

140

19.6

By real-time (live) contact with online professors

123

17.3

Do you learn better by:

\begin{tabular}{lcc}
\hline Reading texts, making summaries, and carrying out activities & 308 & 43.2 \\
\hline Listening to explanations about specific content & 255 & 35.8 \\
\hline Watching videos on the topic & 121 & 17.0 \\
\hline Seeing graphic representations combined with text & 29 & 4.1 \\
\hline Total & 713 & 100.0 \\
\hline
\end{tabular}

Source: Research data, 2015

Note: *imputation $0.1 \%$ of the variable; ${ }^{* *}$ imputation $0.4 \%$ of the variable. ${ }^{* *}$ imputation $0.6 \%$ of the variable.

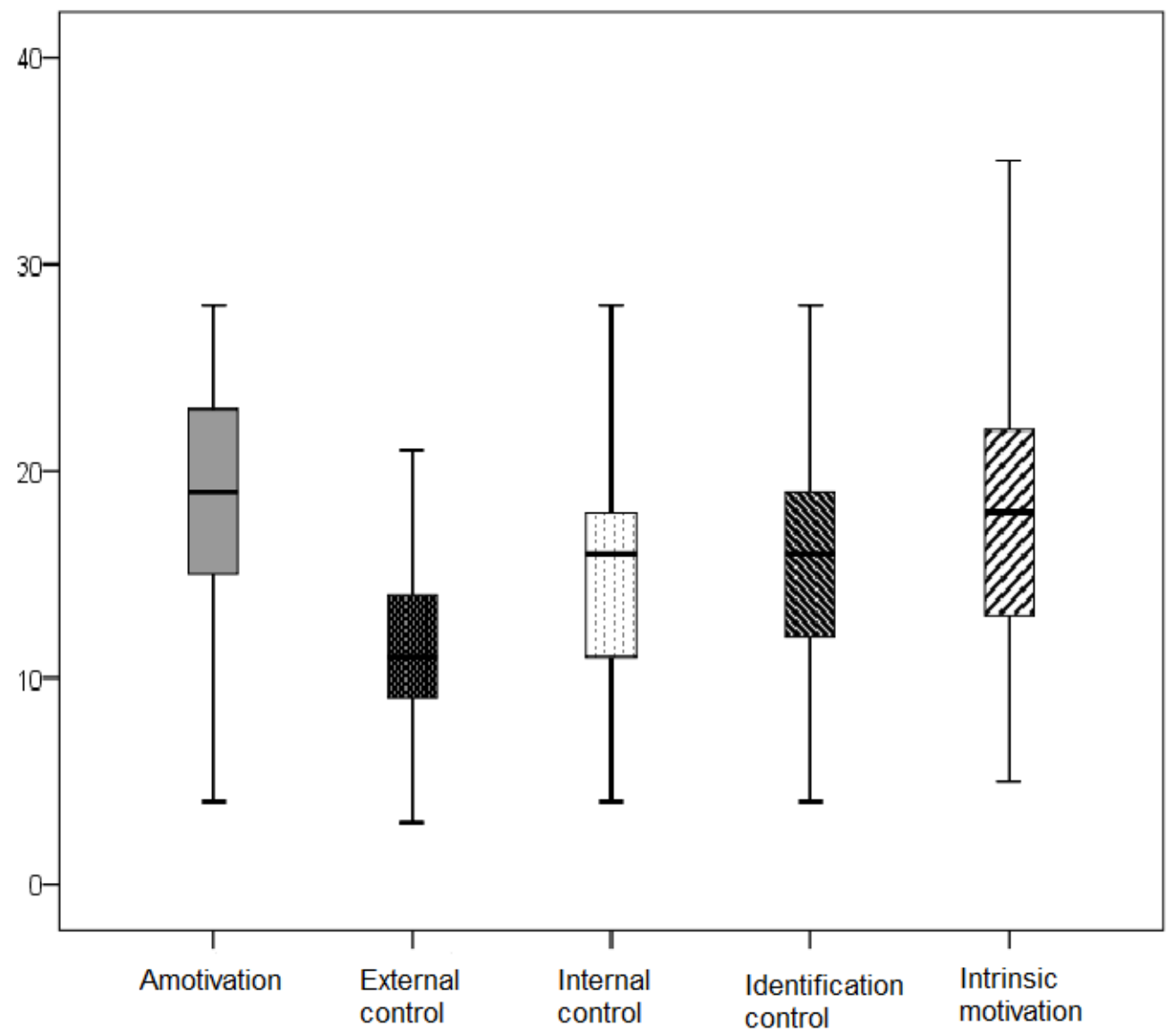

Graph 1 - Distribution of factors of the EMITICE in quartiles. Guarulhos, São Paulo, Brazil, 2015. 
variables: "space for studies," "how students report learning better," and "if they would take online courses." According to post hoc analysis, this difference in the scores on the factor "external control" and variable"space for studies" was among students who reported appropriate vs. inappropriate. When analyzing the variable "how you learn better" by means of the post hoc test in relation to the factor "external control," a statistically significant difference was found between the first and second category. Therefore, students learned better reading texts, making summaries, and carrying out activities to the detriment of listening to explanation about specific content (Table 2).

Table 2 - Statistically significant comparison of variables on structural aspects, use of digital technologies, and ways of studying, according to scores on the factors "external control," "internal control," and "identification control" of the EMITICE scale. Guarulhos, São Paulo, Brazil, 2015

\section{External control}

Regarding your space for studies, do you consider it:

\begin{tabular}{lccccccc}
\hline Appropriate & 316 & 11.4 & $(3.9)$ & 12.0 & 3 & 21 & $\mathbf{0 . 0 3 7}$ \\
\hline Slightly appropriate & 342 & 11.0 & $(4.1)$ & 11.0 & 3 & 21 & \\
\hline $\begin{array}{l}\text { Inappropriate } \\
\text { Do you learn better by: }\end{array}$ & 55 & 9.8 & $(4.9)$ & 11.0 & 3 & 20 & \\
\hline $\begin{array}{l}\text { Reading texts, making summaries, } \\
\text { and carrying out activities }\end{array}$ & 308 & 11.6 & $(4.2)$ & 12.0 & 3 & 21 & $\mathbf{0 . 0 2 8}$ \\
\hline $\begin{array}{l}\text { Listening to explanations about } \\
\text { specific content }\end{array}$ & 255 & 10.6 & $(4.0)$ & 11.0 & 3 & 21 & \\
\hline $\begin{array}{l}\text { Seeing graphic representations } \\
\text { combined with text }\end{array}$ & 29 & 10.7 & $(3.7)$ & 11.0 & 3 & 18 & \\
\hline $\begin{array}{l}\text { Watching videos on the topic } \\
\text { Would you take an undergraduate or graduate online course? }\end{array}$ & 121 & 10.9 & $(4.1)$ & 11.0 & 3 & 20 & \\
\hline Yes & 254 & 12.1 & $(3.6)$ & 12.0 & 3 & 21 & $<0.001$ \\
\hline No & 459 & 10.5 & $(4.2)$ & 11.0 & 3 & 21 & \\
\hline
\end{tabular}

\section{Internal control}

Regarding your space for studies, do you consider it:

\begin{tabular}{|c|c|c|c|c|c|c|c|}
\hline Appropriate & 316 & 15.6 & $(5.3)$ & 16.0 & 4 & 28 & 0.004 \\
\hline Slightly appropriate & 342 & 14.8 & $(5.1)$ & 15.0 & 4 & 28 & \\
\hline Inappropriate & 55 & 12.8 & $(6.4)$ & 13.0 & 4 & 28 & \\
\hline \multicolumn{8}{|l|}{ When accessing the Internet to study: } \\
\hline $\begin{array}{l}\text { Do you stay only on pages related } \\
\text { to content }\end{array}$ & 296 & 14.4 & $(5.3)$ & 15.0 & 4 & 28 & 0.007 \\
\hline $\begin{array}{l}\text { Do you lose concentration by going } \\
\text { to other websites }\end{array}$ & 138 & 14.5 & $(5.3)$ & 15.0 & 4 & 28 & \\
\hline
\end{tabular}


Table 2 - Cont.

\section{Variables}

n

Mean (SD) Median Minimum Maximum p-value

Are you able to reconcile your studies with social networks and other websites, achieving good $\begin{array}{llllll}279 & 15.7 & (5.3) & 16.0 & 4 & 28\end{array}$ results at the end of the semester

Would you take an undergraduate or graduate online course?*

\begin{tabular}{lllllllll}
\hline Yes & 254 & 16.4 & $(4.6)$ & 17.0 & 4 & 28 & $<\mathbf{0 . 0 0 1}$ \\
\hline No & 459 & 14.2 & $(5.8)$ & 15.0 & 4 & 28 & \\
\hline
\end{tabular}

\section{Identification control}

When accessing the Internet to study:

$\begin{aligned} & \text { Do you stay only pages related } \\ & \text { to content }\end{aligned}$
$\begin{aligned} & \text { Do you lose concentration by going } \\ & \text { to other websites }\end{aligned}$

Source: Research data, 2015.

Note: Kruskal-Wallis test ${ }^{*}$ Mann-Whitney test

Comparing the factor "internal control" with IT structural aspects, use of digital technologies, and ways of studying, statistically significant differences were found comparing the following three variables: "space for studies," "how students access the Internet when studying," and "if they would take online courses." When analyzing the variable "about your space for studies, do you consider it," according to the post hoc test, a difference in the score "internal control" was found between values presented for students who reported appropriate vs. inappropriate. The question "when accessing the Internet to study, do you," presented a statistically significant difference with affirmatives for the score "internal control."This difference was found between the first and third categories, showing the importance of students reconciling their studies with social networks and other websites (Table 2).

Statistically significant differences were found when comparing the factor "identification control" with the following variables: "way of accessing the Internet," "when students wish to study," and "if they would take online courses."When analyzing the variable"when accessing the Internet to study, do you" through the post hoc test, a difference was found between the first and third categories, highlighting the importance of students being able to reconcile their use of social networks with their studies to direct their actions toward academic needs (Table 2).

When comparing the factor Intrinsic Motivation with the variables studied, a statistically significant difference was found with the following four variables:"space for studies"," way of accessing the Internet when students need to study", "how they learn better", and "if they would attend online courses". Analysis of the variable "regarding your space for studies, you consider it"according to the post hoc test found differences in the score "intrinsic motivation"among students who reported appropriate versus inappropriate space. After the post hoc test, a statistically significant difference was found between the first and third category for the question "when accessing 
the Internet to study, you" and between the first and second category for the question "you learn better" (Table 3).

Students who would attend online courses presented higher means in the four factors in which statistically significant differences were found, that is, students who answered "yes" have more internal control, external control, identification control, and intrinsic motivation than those who answered "no" in this question (Tables 2 and 3).
Considering variables regarding the questions about IT structure and ways of studying, which seemed to more positively influence motivation of students in online courses, the highest means were found in the following differential categories:"reporting the possibility of attending undergraduate or graduate online courses,"'having an appropriate space for studies at home," and "being able to reconcile studies with social networks or other websites" (Figure 1).

Table 3 - Statistically significant comparison of variables on structural aspects, use of digital technologies, and way of studying according to the score of the factor "intrinsic motivation" of the EMITICE scale. Guarulhos, São Paulo, Brazil, 2015

Variables

n Mean (SD) Median Minimum Maximum p-value

\section{Intrinsic motivation}

Regarding your space for studies, you consider it:

\begin{tabular}{|c|c|c|c|c|c|c|c|}
\hline Appropriate & 316 & 18.6 & $(6.6)$ & 19.0 & 5 & 35 & 0.006 \\
\hline Slightly appropriate & 342 & 17.5 & $(6.5)$ & 18.0 & 5 & 35 & \\
\hline Inappropriate & 55 & 15.4 & $(7.4)$ & 15.0 & 5 & 30 & \\
\hline \multicolumn{8}{|l|}{ When accessing the Internet to study, you: } \\
\hline Only stick to pages related to contents & 296 & 17.0 & $(6.7)$ & 17.0 & 5 & 35 & 0.005 \\
\hline You lose concentration with other websites & 138 & 17.4 & $(6.1)$ & 18.0 & 5 & 33 & \\
\hline $\begin{array}{l}\text { Are able to reconcile your studies with social } \\
\text { networks and other websites, achieving } \\
\text { good results at the end of the semester }\end{array}$ & 279 & 18.9 & $(6.8)$ & 19.0 & 5 & 35 & \\
\hline
\end{tabular}

You learn better:

Reading texts, making summaries, and carrying out activities

$\begin{array}{llll}308 & 18.7 \quad(6.8) \quad 19.0\end{array}$

19.0

5

35

0.017

Listening to explanations on a specific content

$255 \quad 17.0$

$(6.2)$

17.0

5

34

Seeing graphic representations combined with texts

$\begin{array}{llllll}29 & 17.0 & (5.9) & 17.0 & 6 & 28\end{array}$

Watching videos on the topic

$121 \quad 17.6$

(7.2) $\quad 19.0$

5

35

Would you attend any undergraduate or graduate online courses?*

\begin{tabular}{llllllll}
\hline Yes & 254 & 20.1 & $(5.8)$ & 20.0 & 5 & 35 & $<\mathbf{0 . 0 0 1}$ \\
\hline No & 459 & 16.6 & $(6.8)$ & 17.0 & 5 & 35 & \\
\hline
\end{tabular}




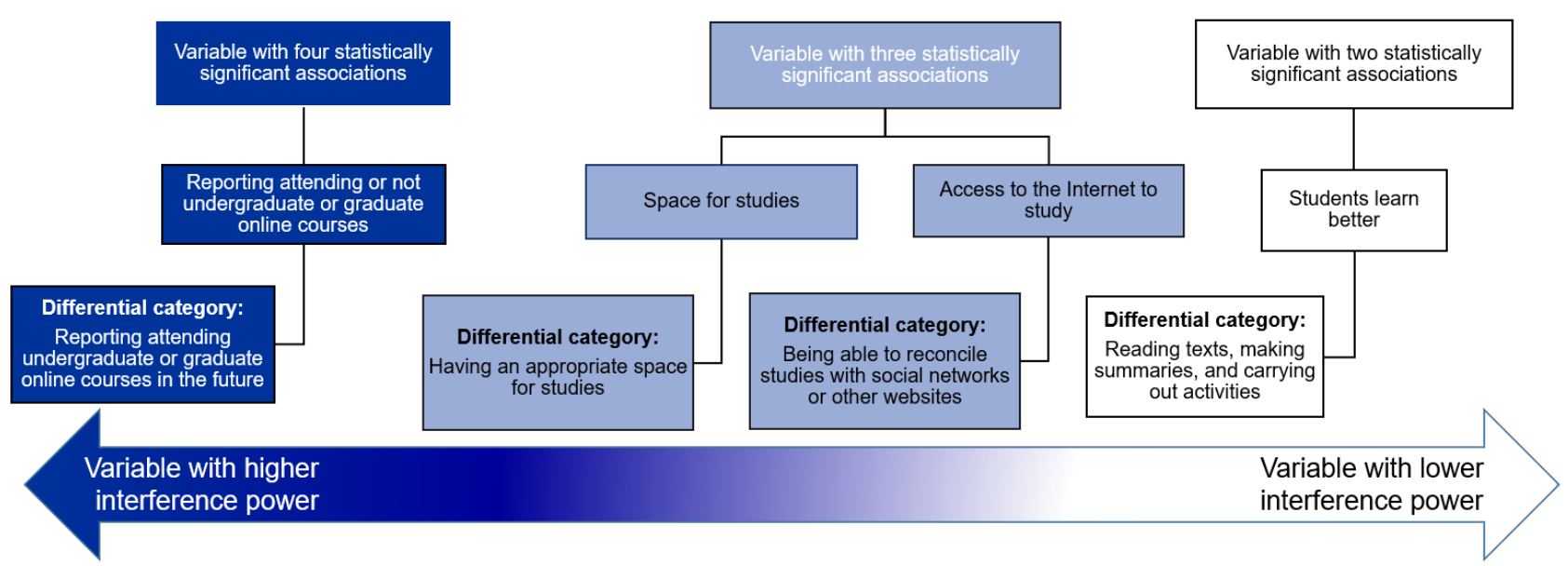

Figure 1 - Description of variables with four, three, and two statistically significant associations with the factors of the scale and differential category according to the post hoc test. Guarulhos, São Paulo, Brazil, 2015.

\section{DISCUSSION}

The results showed that most participants in the study (94.8\%) had computers at home for private use. This data is corroborated by a study ${ }^{(10)}$ carried out in the Republic of Ghana, a country in West Africa, in which $83 \%$ of students in the healthcare area had their own computers, $87 \%$ had appropriate IT knowledge, and 99\% made use of DICTs ${ }^{(10)}$.

When proposing online courses in classroom attendance courses, teaching institutions must be aware of the compatibility of students' structural aspects regarding the use of DICTs in relation to its purpose. Data from the Brazilian National Household Sample Survey (PNAD, as per its acronym in Portuguese) ${ }^{(11)}$ showed that in 2005, 14\% of homes had computers and access to the Internet. In 2015, this number increased to $57.8 \%$, equivalent to 39.3 million homes. In addition, among homes with access to the Internet, $92.1 \%$ (36.2 million) had access by means of cell phones ${ }^{(11)}$.

In the present study, most (76.3\%) of the participants reported being comfortable with the use of computers; however, learning online is different. It requires learning self-regulation of, intrinsic motivation, and independence. It is of the utmost importance to create a virtual environment that promotes the development of these behaviors by students, aiming for successful learning. Nonetheless, the example of a university in the United Kingdom must be considered that compared classroom attendance with online strategies. Hybrid approaches presented better results for motivation, behaviors, satisfaction, and knowledge of nursing students when training in clinical skills ${ }^{(12)}$.
Access by students to IT laboratories of the HEls indicates that IT structure and access to DICTs are relevant factors; however, they are insufficient to motivate students to take online courses. Therefore, teaching strategies, pedagogical mediation $^{(1-2,13)}$, and instructional design with an objectivist and constructivist approach ${ }^{(14)}$ are of the utmost importance. DICTs are tools that must be appropriately implemented by HEls and professors to strengthen the digital abilities of students.

The study participants experienced an instructional model whose learning process is controlled by professors, and the learning environment is structured and followed in a fixed and rigid way. In an analysis of academic practices that made use of virtual environments, researchers showed that transferring models and academic culture to virtual environments reproduced the classroom attendance paradigm. In addition to new implementation of online education, horizontal relationships in virtual spaces must correspond to the redefinition of curricula and academic culture itself, especially in means of evaluation ${ }^{(15)}$.

The model experienced by students corresponds to an objectivist approach, with defined and selected instructional strategies based on mastery and types of learning goals ${ }^{(14)}$. Therefore, it is worth mentioning that this is not the only type of instructional model, and it does not correspond to the current trend of combining approaches.

Online courses with combined instructivist-objectivist and instructivist-constructivist learning strategies may provide positive learning experiences. The mixed-design approach has benefits, because the instructivist-constructivist design has the potential to result in significant 
learning, whereas the instructivist-objectivist design has the advantage of producing appropriate learning from the informational perspective ${ }^{(14)}$.

Another finding that must be discussed is the association of intrinsic motivation and external control with ways of studying. Intrinsic motivation and external control were statistically lower when students reported the need to listen to explanations about specific content. Intrinsic motivation, that is, the interest of individuals, decreased in the face of difficulties with learning only by reading. This is a strong sign that the way of studying may determine performance and ease of students in this teaching modality. In addition, it may be considered a predictive factor in follow-up with students, directing the planning of online courses with more technological learning resources, avoiding evasion.

Self-determined motivation of students is positively associated with different cognitive, affective, and behavioral results, which may be improved by changes in educational environments and early detection of student characteristics ${ }^{(16)}$.

Although students reported the need to listen to explanations for better understanding, analysis of the item by the post hoc test showed an emphasis on learning better when making summaries and carrying out activities. There is a clear contradiction in the results; however, it may indicate the relational aspect of the learning process and the need for support in organizing and carrying out activities.

Teaching and learning are increasingly associated with the communication process and student-professor-institution relationships. These relationships may directly influence performance and motivation of students, in both online and classroom attendance teaching. Pedagogical mediation highlights the importance of student participation, responsibilities and goals to be accomplished, discussions among individuals involved, and organization to meet established deadlines. The role of tutors is of the utmost importance, because they mediate knowledge $\mathrm{e}^{(1,13)}$.

Pedagogical mediation, from the perspective of self-determination theory, must value respectful relationships between professors and students. When encouraging professionals to include the choice in their plans and value a human-based approach, the purpose of enhancing knowledge to improve classroom attainment is highlight$\mathrm{ed}^{(17)}$. An attuning and guiding approach is associated with a more adaptable, effective, and significant standard in professor/student relationships. However, a contrasting standard is found for an approach based on imposition and neglect ${ }^{(18)}$. Therefore, offering online courses does not exempt communication and relationship between students and professors/tutors.
Relevance seems to have an important role in motivation, because the results suggest that the more students integrate the importance of the use of DICTs into their other values and opportunities, the more interested students are in using them, identifying personal rewards, and deciding to engage in more direct actions to carry out activities.

The inclusion of technological advances in healthcare systems is not limited to the university context; however, it implies challenges in training a qualified workforce by and for the use of DICTs. The experience of including new digital technologies in nursing care has presented barriers such as lack of familiarity, need for local infrastructure (access to the Internet), and routine refusal to adapt by professionals ${ }^{(19)}$. Lack of familiarity with new technologies may be minimized by better use of DICTs, starting in training. The authors of one study said that improving confidence and mastery of undergraduate students in the use of DICTs may positively influence their future behavior regarding the use of DICTs in healthcare contexts ${ }^{(20)}$.

The inclusion of new digital technologies in education and professional contexts is something that tends to increase exponentially and requires further studies, strategies, and reflections, so individuals are appropriately adapted and included in the development process related to the digital era.

\section{CONCLUSIONS}

A predisposition to take online courses, having an appropriate space to study, and reconciling study with the use of other websites were positive elements for the motivation of students in online courses. The way students report learning better, that is, reading, listening, seeing graphics, or watching videos, also affected motivation in online courses, which is obviously an important aspect that must be considered in the development of programs and online courses. Different ways of learning must be considered in order to develop an appropriate profile for inclusion.

The limitations of the present study include non-randomization of the participants and the cross-sectional nature of the data collection, which only allowed associations. The data collection instruments made up of multiple-choice questions, and because the present study was carried out in a single HEI, so the results are applicable to a specific context and a single online course model. However, the present study contributes to the recognition of structural and technological aspects and students' ways of studying as factors that must be considered in the planning, implementation, and evaluation of online courses and programs, as well as in the learning process. 


\section{REFERENCES}

1. Bacich L, Moran J (organizadores). Metodologias ativas para uma educação inovadora: uma abordagem teórico-prática. 1ª ed. Porto Alegre: Penso; 2018.

2. Oliveira MR, Correia VGA, Dantas EOM, Moreira TMM, Torres RAM. Validação da escala de atitude em tecnologias digitais da informação e comunicação. Acta Paul Enferm. 2019;32(1):79-86. doi: https://doi. org/10.1590/1982-0194201900011

3. Wanderley TPS, Batista MHJ, Dutra Júnior LS, Silva VC. Docência em saúde: tempo de novas tecnologias da informação e comunicação. Rev Eletron Comun Inf Inov Saúde. 2018;12(4):488-501. doi: https://doi.org/10.29397/reciis. v12i4.1522

4. Moran JM. Propostas de mudança nos cursos presenciais com a educação "online". Rev ABENO. 2005 [cited 2018 out 9];5(1):40-5. Available from: http:// www.eca.usp.br/prof/moran/site/textos/educacao_online/propostas.pdf

5. Bernardino AO, Coriolano-Marinus MWL, Santos AHS, Linhares FMP, Cavalcanti AMTS, Lima LS. Motivation of nursing students and their influence in the teaching-learning process. Texto Contexto Enferm. 2018;27(1):e1900016. doi: https://doi.org/10.1590/0104-070720180001900016

6. Deci EL, Ryan RM. The "what" and "why" of goal pursuits: Human needs and the self-determination of behavior. Psychol Inq. 2000;11(4):227-68. doi: https:// doi.org/10.1207/s15327965pli1104_01

7. Fiuza PJ, Sarriera JC, Bedin LM. Educação a distância: tradução, adaptação e validação da escala de motivação EMITICE. Psicol Esc Educ. 2013;17(1):45-53. doi: https://doi.org/10.1590/S1413-85572013000100005

8. Siqueira AL, Tibúrcio JD. Estatística na área da saúde: conceitos, metodologia, aplicações e prática computacional. 1a ed. Belo Horizonte (MG): Coopmed; 2011.

9. Pedersen AB, Mikkelsen EM, Cronin-Fenton D, Kristensen NR, Pham TM, Pedersen $L$, et al. Missing data and multiple imputation in clinical epidemiological research. Clin Epidemiol. 2017;9, 157-166. doi: https://doi.org/10.2147/CLEP. S129785

10. Dery S, Vroom FD, Godi A, Afagbedzi S, Dwomoh D. Knowledge and use of information and communication technology by health sciences students of the University of Ghana. Ghana Med J. 2016 [cited 2018 0ct 9];50(3):180-8. Available from: https:/www.ncbi.nlm.nih.gov/pmc/articles/PMC5044793/ pdf/GMJ5003-0180.pdf

11. Instituto Brasileiro de Geografia e Estatística. Acesso à internet e posse de telefone móvel celular para uso pessoal 2015. Rio de Janeiro; 2016 [cited 2018 0ct 9]. Available from: https://biblioteca.ibge.gov.br/visualizacao/livros/ liv99054.pdf

\section{- Corresponding author:}

Ana Claudia Giesbrecht Puggina

E-mail: claudiagpuggina@gmail.com
12. McCutcheon K, O'Halloran P, Lohan M. Online learning versus blended learning of clinical supervisee skills with pre-registration nursing students: a randomised controlled trial. Int J Nurs Stud. 2018;82:30-39. doi: https://doi.org/10.1016/j. ijnurstu.2018.02.005

13. Cavalcante RB, Diniz FA, Oliveira PP, Quites HFO, Machado RM, Gontijo TL. Student permanence in distance education: a challenge in health managers' training. Cogitare Enferm. 2017;22(2):e49221. doi: https://doi.org/10.5380/ ce.v22i2.49221

14. Chen SJ. Instructional design strategies for intensive online courses: an objectivist-constructivist blended approach. J Interact Online Learn. [cited 2019 Nov 22]; 2007;6(1): 72-86. Available from: http://citeseerx.ist.psu.edu/ viewdoc/download?doi=10.1.1.464.7048\&rep=rep1\&type $=$ pdf

15. Silva LTG, Bezerra IS. Hibridações da cultura acadêmica com a cibercultura: análise das práticas acadêmicas no ambiente virtual de aprendizagem Moodle. Educ Rev. 2018. [citado 2019 set 04];34:e186802. Disponível em: https://doi. org/10.1590/0102-4698186802

16. Orsini C, Binnie VI, Wilson SL. Determinants and outcomes of motivation in health professions education: a systematic review based on self-determination theory. J Educ Eval Health Prof. 2016;13:19. doi: https://doi.org/10.3352/ jeehp.2016.13.19

17. Moss JD. Inviting autonomy: common roots and beliefs of self-determination theory and invitational education theory. J Invitat Theory Pract. 2019 [cited 2019 Nov 22];24:34-45. Available from: https://www.researchgate.net/ publication/330116843_Inviting_Autonomy_Common_Roots_and_ Beliefs_of_Self-determination_Theory_and_Invitational_Education_Theory

18. Aelterman N, Vansteenkiste M, Haerens L, Soenens B, Fontaine JRJ, Reeve J. Toward an integrative and fine-grained insight in motivating and demotivating teaching styles: the merits of a circumplex approach. J Educat Psychol. 2019;111(3):497-521. doi: https://doi.org/10.1037/edu0000293

19. Vossebeld DM, Puik ECN, Jaspers JPT, Schuurmans MJ. Development process of a mobile electronic medical record for nurses: a single case study. BMC Med Inform Decis Mak. 2019;19:11. doi: https://doi.org/10.1186/s12911-018-0726-3

20. Silva LTG, Bezerra IS. Hibridações da cultura acadêmica com a cibercultura: análise das práticas acadêmicas no ambiente virtual de aprendizagem Moodle. Educ Rev. 2018; 34:e186802. doi: https://doi.org/10.1590/0102-4698186802

\section{Acknowledgements:}

To the Coordination for the Improvement of Higher Education Personnel CAPES, for the support provided to the Nursing Graduate Program of UNG, with the concession of Master's school taxes.
Associate editor:

Wiliam Wegner

Approved: 02.12.2020

\section{Editor-in-chief:}

Maria da Graça Oliveira Crossetti 